\title{
Historical perspectives of The American Association for Thoracic Surgery: Edward D. Churchill (1895-1972)
}

\author{
Cameron D. Wright, MD
}

Edward Delos Churchill, the 28th president of The American Association for Thoracic Surgery (AATS), was born on Christmas Day, 1895, in Chenoa, Ill. He graduated from Northwestern University in 1916, obtained a master's degree in biology in 1917, graduated from Harvard Medical School cum laude in 1920, and completed surgical residency at the Massachusetts General Hospital (MGH) in 1924. Churchill was nonplussed regarding his residency, noting, "What I found most disturbing at the time, and now in retrospect-was the attitude of complacency, the smug suppression of intellectual curiosity...The surgeons were anti-scientific and anti-intellectual in their attitudes and in the example they were setting for the oncoming generation." After his training, Churchill stayed at the MGH, primarily serving as an assistant surgeon. During his first year, he also spent time in Cecil Drinker's physiology laboratory, and he was awarded a Moseley Traveling Fellowship in 1926 to study abroad. He traveled primarily to Copenhagen, where he worked with the physiologist August Krogh, but he also visited 2 of the giants of thoracic surgery of that era, Brauer and Sauerbruch. Churchill returned to the MGH in 1927 under Edward P. Richardson, the John Homans Professor of Surgery.

In July of 1928, cardiologist Paul Dudley White consulted Churchill about a patient with constrictive pericarditis. White thought that the patient should undergo a Brauer pericardiolysis, but Churchill instead performed an operation suggested by Delorme and Sauerbruch. Churchill performed the first extended pericardiectomy in the United States, and the patient made a splendid recovery, thus launching Churchill's academic surgical career. ${ }^{2}$ Shortly thereafter, Churchill was promoted to associate professor and moved to the Boston City Hospital to start an academic Harvard surgical unit; however, he was not welcomed by the private practice surgeons on staff and was not granted surgical privileges. It was a very challenging time for him; clearly the time was not right for a surgeon-scientist at Boston City Hospital. Richardson had Churchill return to the

\footnotetext{
From the Department of Thoracic Surgery, Massachusetts General Hospital, Boston, Mass.

Received for publication Feb 18, 2011; accepted for publication June 28, 2011; available ahead of print Aug 8, 2011

Address for reprints: Cameron D. Wright, MD, Massachusetts General Hospital, Thoracic Surgery, Blake 1570, 55 Fruit St, Boston, MA 02114 (E-mail: wright. cameron@mgh.harvard.edu).

J Thorac Cardiovasc Surg 2012;143:1-3

$0022-5223 / \$ 36.00$

Copyright (c) 2012 by The American Association for Thoracic Surgery doi:10.1016/j.jtcvs.2011.06.032
}

MGH in 1930. His initial plan was for Churchill to concentrate his efforts in the laboratory, but Richardson sustained an incapacitating stroke later that year, which changed everything. Churchill succeeded Richardson as the John Homans Professor of Surgery and Chief of the West Surgical Service in 1931.

In collaboration with his brilliant pupil John H. Gibbon, Jr, the 40th AATS president, Churchill's early research centered on cardiopulmonary physiology with a special interest in pulmonary embolism. Churchill and Gibbon demonstrated that multiple small pulmonary emboli increased pulmonary vascular resistance and caused right heart failure, whereas a single massive embolism was lethal by some other unknown means. They brought light to the paradox that ligature of the pulmonary artery was well tolerated, whereas an acute embolism was usually fatal. The need for temporary cardiopulmonary support was born in these laboratory investigations and led to Gibbon's development of the cardiopulmonary bypass machine.

Churchill was a true intellectual with a grounding in the classics, but he was also an original thinker with prescient ideas. During his early years of practice, he made contributions to surgery for hyperparathyroidism, constrictive pericarditis, pulmonary embolectomy, esophagectomy, and lobectomy for bronchiectasis. His early results with lobectomy for bronchiectasis were remarkably good, which he attributed to proper medical preparation of the patients, avoidance of surgery in the winter (when respiratory infections were rampant), ensuring proper nutrition, and meticulous hilar dissection with individual vessel ligation. Churchill reported the results of his first 78 lobectomies at the AATS annual meeting in 1936 to a dumbfounded audience. His mortality was less than $5 \%$, which compared favorably with the lowest previously reported mortality of $18 \%$ by John Alexander, 17 th AATS president. ${ }^{3}$ Churchill's productivity in surgery was likely due to 3 factors: (1) Fundamentally, he was a biologist first, which enabled him to have unusual insight into the pathophysiology of disease. (2) He was a consummate surgical technician. (3) He had a gift for both the spoken and written word, which facilitated the transmission of his ideas and opinions.

In the late 1930s, Churchill designed his new surgery residency program. Unlike the pyramidal Halstead model, the $\mathrm{MGH}$ established a rectangular program that finished the same number of residents that it accepted as interns. Churchill believed if the residents were chosen wisely, they would work both hard and together, obviating the destructive competition in the Halstead model of surgical 


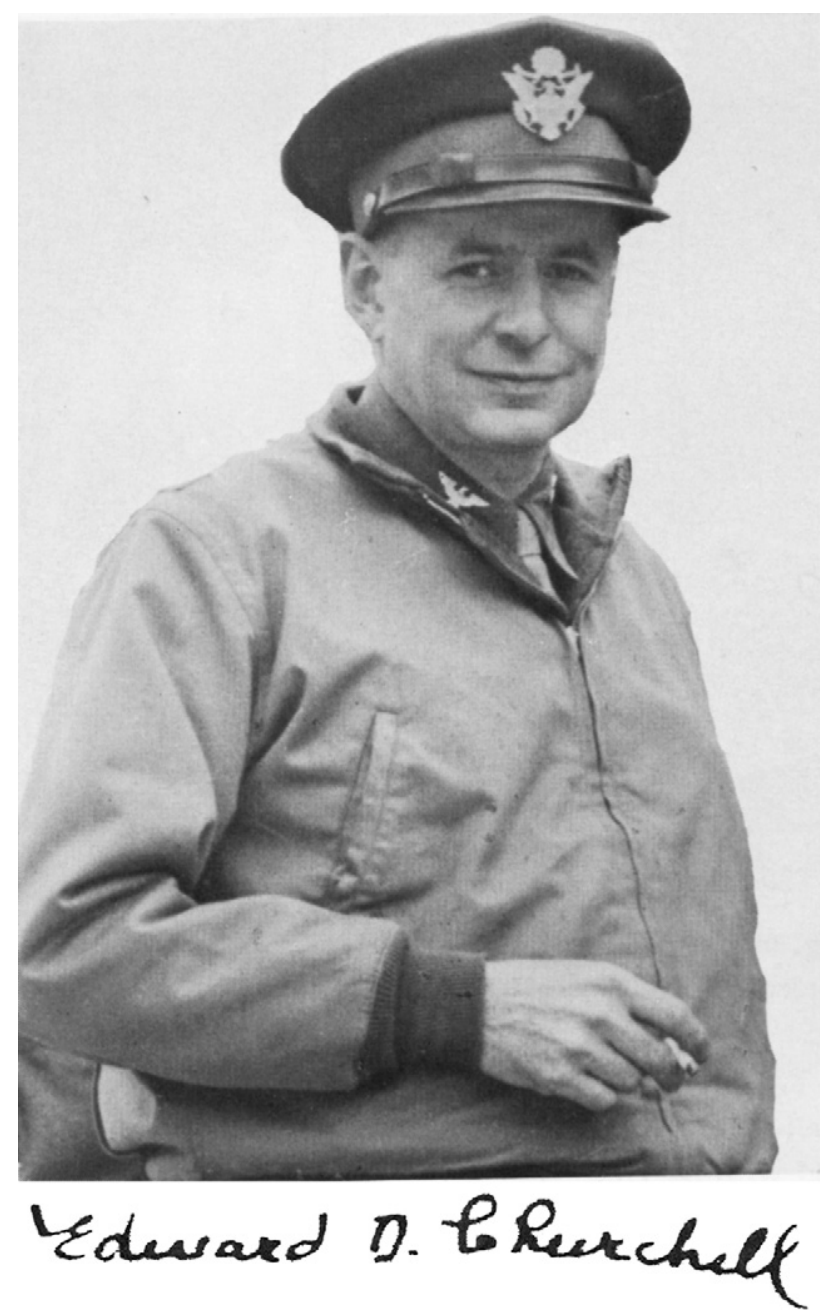

FIGURE 1. Colonel Churchill and his signature.

training. Churchill's unique scheme continues to this day at the MGH and serves as the model for all US surgical training programs.

In 1943, Churchill volunteered to serve in World War II as Colonel and Consulting Surgeon for the North African and Mediterranean Theaters of Operations (Figure 1). He had a comfortable collegial relationship with British and American surgeons, and, after learning of their numerous wartime problems, instituted solutions to many military surgical dilemmas. Churchill helped to institute the policy of adequate débridement and delayed primary closure of war wounds, early use of whole blood transfusions, establishment of regional blood banks, and the use of air evacuation of wounded soldiers. His younger officers formed the Excelsior Society and Edward D. Churchill Lectureship to honor the Colonel and maintain the bonds they had developed overseas. Churchill was awarded the Distinguished Service Medal for his accomplishments during the war and summarized his wartime experiences in Surgeon to Soldiers. ${ }^{4,5}$ By all accounts, his World War II experience had
THE SURGICAL MANAGEMENT OF THE WOUNDED IN THE MEDITERRANEAN THEATER AT THE TIME OF THE FALL OF ROME

Colonel Edward D. Churchill, m. c., A. U. s.

"I would remind you again how large and various was the experience of the battleficld, and how fertile the blood of warriors in rearing good surgeons."

\author{
T. Cimfrord Alibutr.
}

FIGURE 2. Perhaps the most dramatic title ever recorded for a surgical paper.

a profound effect on his life and influenced his subsequent path. When he returned to Boston, he bought a Jeep and commuted back and forth from Belmont, Mass, in the same type of vehicle he used in the War. In 1944, he submitted to the American Surgical Association in absentia regarding his war experience an article with perhaps the most dramatic title ever recorded for a surgical paper (Figure 2). ${ }^{6}$

When Churchill returned to Boston, the hospital had changed, and his practice was gone. He was appointed to the Hoover Commission's Committee on Federal Medical Services to reorganize the Medical Corps of the Department of Defense, but after a few years of frequent commuting to Washington, DC, he left public service once and for all, completely discouraged and frustrated with governmental bureaucracy. He then devoted his efforts back home to rebuilding the surgical staff, which had been decimated by the war, and to reestablishing the research and residency training efforts within the department of surgery at MGH. ${ }^{7}$

Churchill was not a proponent of surgical specialization and believed in the preeminence of the general surgeon. Nowhere was this more evident than in his lack of enthusiasmor as some would say "blind spot" - for cardiac surgery. One can trace this back to the war years, during which Richard Sweet, 41st AATS president, started a thoracic surgery residency at MGH during Churchill's absence. Three residents completed thoracic training under Sweet before Churchill returned and closed the program. Churchill believed that the modern surgeon needed to be grounded in general surgery and biology; he disdained technicians who did not have a scientific foundation. He summarized his negative feelings toward the technical modernization of surgery that was occurring in the late 1950s as follows: "The invention of some gadget facilitates a technical breakthrough into new territory-conquest by instrumentation becomes as soulless as a blitzkrieg." ${ }^{\prime}$ In the early 1960s, Churchill's viewpoint towards cardiac surgery changed as he realized the importance of the specialty and initiated its development at the MGH. Just before W. Gerald Austen, 69th AATS president, left for the National Institutes of Health in 1961, Churchill told Austen that he had been wrong about heart surgery and was delighted that he would focus on this emerging field (W.G. Austen, personal communication, February 2011).

Churchill was president of the American Surgical Association in 1946, and his presidential address, "Science and 


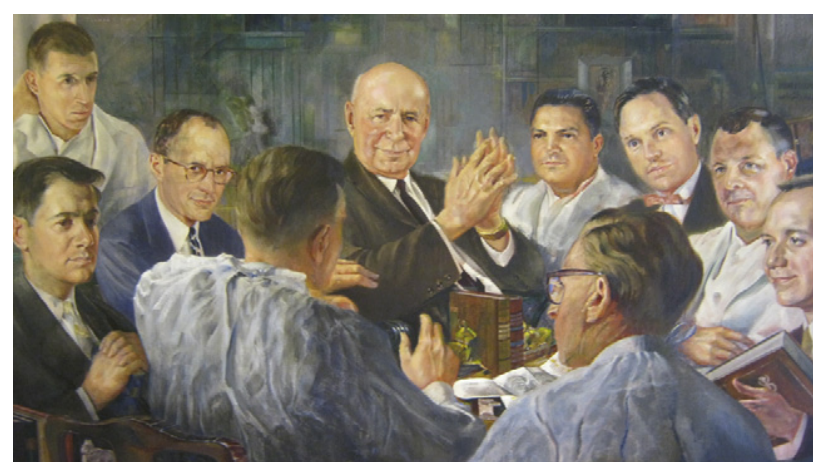

FIGURE 3. Churchill's official portrait, with his residents.

Humanism," focused on the intellectual trends in the field of surgery. ${ }^{9}$ In contrast, his AATS presidential address in 1949, "The Segmental and Lobular Physiology and Pathology of the Lung," was an erudite discourse on segmental pathophysiology of the lung, reinforcing his sentiments of the importance of science in surgical practice. $^{10}$

Churchill had a stroke in 1953, and although he made a good functional recovery, his surgical practice was limited thereafter. The final years of his career focused on the education and mentoring of both residents and young faculty. Churchill was a seasoned clinician with superb judgment and a paternal method of teaching. He cherished his residents, always protecting their autonomy to foster their development. This is perhaps best exemplified by Churchill's insistence that his formal hospital portrait depict him on his professorial rounds with his residents (Figure 3).

After his retirement in 1962, Churchill focused his scholarly attention on the history of military wound management. He withdrew from Boston and spent most of his time on his Vermont farm with his wife, Mary. On August 28, 1972, while walking on his farm, he had a fatal myocardial infarction. That year, Harvard Medical School honored him with a named chair. His pupil Austen was named the first Edward D. Churchill Professor of Surgery in 1974.

\section{References}

1. Churchill ED, Scannell JG, eds. Wanderjahr: the education of a surgeon. Boston: Science History Publications; 1991.

2. Austen WG. Eight former presidents of the AATS. The Boston connection. $J$ Thorac Cardiovasc Surg. 1989;98:643-58.

3. Churchill ED. Lobectomy and pneumonectomy in bronchiectasis and cystic disease. J Thorac Surg. 1937;6:286.

4. Moore FD. Edward Delos Churchill: 1895-1972. Ann Surg. 1973;177:507-8.

5. Churchill ED. Surgeon to soldiers. Philadelphia: Lippincott Williams \& Wilkins; 1972 .

6. Churchill ED. The surgical management of the wounded in the Mediterranean theater at the time of the fall of Rome [Foreword by Brig. Gen'l Fred W. Rankin, M.C.]. Ann Surg. 1944;120:268-83.

7. Cope O. In honor of Edward Delos Churchill. Ann Surg. 1963;158:731-9.

8. Churchill ED, ed. To work in the vineyard of surgery: reminiscences of J. Collins Warren, 1842-1927. Cambridge (MA): Harvard University Press; 1958.

9. Churchill ED. Address of the President: Science and humanism in surgery. Ann Surg. 1947;126:381-96.

10. Churchill ED. The segmental and lobular physiology and pathology of the lung J Thorac Surg. 1949;18:279-93. 